\title{
An Interventional Comparative Study in Reducing The Perceived Stress among Employees of Hubli with Shirolepa and Shiropichu along with Concomitant Treatments
}

\author{
Dr. Prayagaprasad U R ${ }^{1}$, Dr. Prashanth A $S^{2}$ \\ ${ }^{1}$ Final Year MD Scholar, ${ }^{2}$ Principal, Head and Professor \\ Department of Kayachikitsa, \\ Ayurveda Mahavidyalaya and hospital Hubli, Karnataka, India
}

\begin{abstract}
Today is the era of modernization and fast life where everybody is busy and living a stressful life. Advancement of busy, professional and social life, continuous work and overexertion, changing life style of modern human being has created several disharmonies in his biological system. The present clinical study was conducted in Ayurveda Mahavidyalaya and Hospital Hubli to compare the combined effectiveness of Shirolepa \& Shiropichu in Reducing the Perceived Stress in Employees along with Concomitant Treatments in Chittodwega caused by Occupational stress.
\end{abstract}

The research Question of the study were: Whether the combined effect of Shirolepa with concomitant treatment significantly decrease the signs and symptoms of Occupational stress vis-a-vis Chittodwega ; the scores of Professional life stress scale and DSM V when compared to Shiropichu with Jyothismathi tailam followed by concomitant treatments.

The design of the study was Open Labeled Double Arm (Uncontrolled) Exploratory Clinical Trail.

Overall effect of therapy showed that, $70 \%$ patient was cured or markedly improved at the end of 60 days of treatment in the Shirolepa group. $30 \%$ patients gained moderate improvement. While in the Shiropichu group $35 \%$ of patients gained marked improvement, $60 \%$ were moderately improved while $5 \%$ were having mild improvement.

Hence, it can be concluded that, improvement in the Shirolepa group was more significant and consistent as compared to Shiropichu group.

By seeing the results it's evident that no patient had complete remission after Shirolepa/Shiropichu followed by Nasya i.e. on 15th day. This implies that only Shirolepa or Shiropichu is insufficient for the management of Chittodwega (OS). After completion of the treatment (60days) Subjects got marked relief in the symptoms. So the present study was ideal for Occupational stress having a package of treatments for long duration.
Keywords:- Occupational Stress, Chittodwega, Shiropichu, Shirolepa, Professional Life Stress Scale, DSM V

\section{INTRODUCTION}

The $21^{\text {st }}$ century is called "The Century of Stress"[1] because there will not be a single person without stress. From the little child to old person each one is having stress. Compensation claims for all stress related disorders are growing in number while all other disabling work injuries are decreasing. Epidemiological studies can explore the relationship between Psychiatric morbidity and work environment and their findings may help in prevention of such morbidity.

Occupational stress is a known health risk for a range of Psychological, Behavioral, and Medical disorders and diseases. Employees stress is a growing concern for organizations today. Organizations and individuals can mitigate these disorders through preventive stress management and enhanced wellbeing. The reported prevalence rates of Psychiatric morbidity in Indian industrial population range from $\mathbf{1 4 \%} \mathbf{- 3 7 \%}$ and can be up to as high as $74 \%$ in Western reports. A survey on workers shown that $40 \%$ of them are extremely stressful with their job, $25 \%$ viewed it as the number one stressor in their life. Stress is linked to the six leading causes of death- heart disease, lung ailments, accidents, cirrhosis of liver, and suicide. Research in the field of work and family has well established the spill over and cross over effects of stress affecting co-workers, spouse, children, and the community at large.

Life is a conglomerate of Shareera (body), Indriya (faculties), Satva (mind), and Atma (soul). Any of these cannot be isolated and studied separately. So seers of Ayurveda express that the term "Shaareera" refers body including five senses and mind. ${ }^{[2]}$ In Ayurvedic Classics ${ }^{[3]}$ three basic attributes of personality Satwa, Rajas and Tamas are elaborately discussed along with Description of Manas ,Dosas and Vikaras. Kama, Krodha, Lobha, Moha, Irshya, etc. are normally found in everybody but when these Doshas and Vikaras get out of proportion they lead to Manasa vikaras/ Mano vikruti. Ayurveda considers the Human body 
as an inverted tree wherein the roots are at the top and branches pointing downwards. If the Human body is considered to be a Tree- The head of the Human body will be considered to be the roots of this tree. Head is an abode of the remote control of the entire body- 'The Brain and Nerves' and all the components which keep us attached and attracted to this material world'. For this reasons, the Head is called as the 'Uttamanga'. Hence, to keep the mind calm in this stressful lifestyle, to have good sleep and ultimately in controlling the mind, treatment modalities like Shirolepa are explained even though only remote reference are seen in the Classical texts, but is well evidenced in relieving stress and drugs which are Sheetaveerya dravya and Medyadravyas ${ }^{[4]}$ are chosen to evaluate their efficacy etc. and medicaments selected are generally according to the Dosha predominance..

Nasya karma is another treatment modality for Manasika vikaras and Shiro rogas as Acharyas has mentioned that Sthana of Manas as Shirasthalu anthara gatam manaha and the treatment Nasya is considered as the best treatment because Nasa hi shiraso dwaram ${ }^{[5]}$; nasal route is having direct entry to CNS. Keeping these treatment principles in mind, Samanya Manasa Roga Chikista, Manasa Dosha Hara Bheshaja prayoga, administration of Medya and Manobala vardhaka dravyas can be selected for the treatment

Ayurveda explains clearly in Vaidyakiya Subhashita that Abhaya Dana is Sarva Shreshta Dana among danas, where Satwavajaya chikista plays a very major role in treating Manasika rogas. Satwavajaya chikitsa ${ }^{[6]}$ which is nothing but keeping the rogi away from ahita vishayas, or ahita vichara with the aid of harsha, aashwasana, dhairya etc. It's nothing but counseling subjects and trying to divert his/her mind to optimism or the positive thoughts. So according to the mental status of subjects, suitable behavioral therapy was adopted. Hence in the present study, an effort is made to Compare the clinical efficacy of Shirolepa and Shiropichu along with Nasya, Satwavajaya chikitsa and Shamanaushadi (Anubhuta yoga) in two different groups of minimum 20 patients each through various observations and statistical methods. If it can provide a good work-life balance, an individual can achieve better health, wellness and greater job satisfaction.

\section{OBJECTIVES}

\section{$>$ Aim of the Study:}

1. To provide good work-life balance, wellness and greater job satisfaction for the welfare of mankind.

\section{$>$ Objectives of the Study:}

1. To evaluate the combined effect of SHIROLEPAM in perceived stress of employees in different organizations along with Nasya, Satvavajaya and Shamanoushadi.

2. To evaluate the combined effect of SHIROPICHU in perceived stress of employees in different organizations along with Nasya, Satvavajaya and Shamanoushadi.

3. To evaluate and compare the combined effect of SHIROLEPAM and SHIROPICHU in perceived stress of employees.
4. To study STRESS and CHITTODWEGA according to Modern and Ayurvedic literature in detail.

\section{MATERIALS AND METHODS}

Study design: Open labeled double arm (uncontrolled) exploratory clinical trial.

Study duration: The total duration of the study was 60 days Study population: Minimum of 40 Subjects fulfilling the inclusion and exclusion criteria were randomly categorized into 2 groups as Group A and Group B having 20 subjects each.

$>$ Plan of work

The entire study was designed to be conducted in three phases.

- PHASE I

$\checkmark$ Detailed literature review, done extensively using tertiary resources, secondary resources, primary resources

$\checkmark$ Procure the necessary documentation: Designing of data entry form, informed consent document, patient information sheet.

$\checkmark$ Ethical committee approval: Ethical clearance was obtained from the Institutional Ethics Committee of Ayurveda Mahavidyalaya Hubli.

- PHASE II

$\checkmark$ The sample size was collected which comes under the inclusion and exclusion criteria at the time of enrolment.

$\checkmark$ Data was collected using data entry form after explaining patient information sheet and signing informed consent document.

- PHASE III

$\checkmark$ Reports were analyzed using various statistical tools.

$\checkmark$ Reporting of results and presentation.

\section{Study criteria}

$>$ Patients were selected based on the following

Inclusion and exclusion criteria:

* Inclusion Criteria

$\checkmark$ Diagnosed case of occupational induced stress.

$\checkmark$ Age group between 20-50 years.

$\checkmark$ Subjects of both gender, irrespective of socio-economic status.

$\checkmark$ Subjects with mild hypertension.

* Exclusion Criteria

$\checkmark$ Stress due to substance abuse / trauma.

$\checkmark$ Physiological conditions like pregnancy, lactation and puerperal stage.

$\checkmark$ Subjects who are unfit for Shirolepa, Shiroichu, Nasya.

\section{Sources of data:}

Patient interview and patients case records which contain the patient's demographics, history, laboratory investigation reports and prescribed drugs.

\section{Study materials :}

$\checkmark$ Informed Consent Form and Patient Information Sheet

To enroll patients in the study, informed consent and patient information sheet was prepared. 


\section{$\checkmark$ Patient Data Entry Form}

For collecting the necessary data obtained from the sources, separate data entry form was designed by including demography of patients, date of admission, past medical and medication history, diagnosis, current medication, Professional life stress scale and DSM V.

\section{Study Procedure:}

An open labeled exploratory trial entitled $A$ randomized comparative clinical study to evaluate the efficacy of Shirolepa \& Shiropichu in reducing the perceived stress in employees along with concomitant treatments; was conducted on 44 patients of age 20 years and above, with a clinical diagnosis of perceived stress from work were randomly arranged into 2 groups.
Group 1 received Shirolepa whereas the other received Shiropichu. The comparison of was done among both the groups to assess effectiveness using Professional life stress Test which includes 24 questionnaires with scoring;

Score $=0-15$. Stress isn't a problem in individual's life

Score $=16-30$. This is moderate range of stress for a busy professional person

Score $=31-45$. Stress is clearly a problem, and the need for remedial action is Apparent.

Score $=46-60$. At these levels, stress is a major problem, and something must be done without delay.

The individuals with score more than 16 were considered for the study.

\section{RESULTS}

Total of 44 Subjects were taken for the clinical trial, with 22 Subjects in each group.

\begin{tabular}{|c|c|c|c|c|c|}
\hline Subjects screened & Withdrawal & Group & Included & Dropout & Completed \\
\hline \multirow{3}{*}{52} & \multirow{3}{*}{08} & $\mathrm{~A}$ & 22 & 02 & 20 \\
\cline { 3 - 6 } & & $\mathrm{B}$ & 22 & 02 & 20 \\
\cline { 3 - 6 } & & TOTAL & 44 & 04 & 40 \\
\hline
\end{tabular}

Table 1:- Study Chart

\section{Effect of Therapies}

Total 52 Subjects who Perceived Stress at work place were registered for the study; out of which 08 were withdrawn and rest 44Subjects were included in study from which 04 were dropped out. So the subjects who completed the study are 40. The effects of the therapy in those 40 subjects are being shown here under the separate headings.

All the symptoms and DSM V were scored on selfprepared scale, professional stress scale score was put as per the scale, and those scores were analyzed with statistical analyzing software.

Friedman's test was applied to see the significant change in the symptoms and other ordinal data. Wilcoxon signed rank test with Bonferroni correction was applied as post hoc test for symptoms which showed significance in Friedman's test to interpret the time of significant change. Mann-Whitney U test is applied to compare the effectiveness in both groups.

\begin{tabular}{|c|c|c|c|c|c|c|}
\hline Parameter & & $\mathbf{N}$ & Cochran Q & Df & P value & Remarks \\
\hline $\begin{array}{l}\text { Anxiousness } \\
\text { BT-DT }\end{array}$ & A & 18 & 6.000 & 1 & 0.014 & $\mathrm{~S}$ \\
\hline $\begin{array}{c}\text { Irritability \& Restlessness } \\
\text { BT-DT }\end{array}$ & $\mathrm{A}$ & 16 & 10.000 & 1 & 0.002 & $\mathrm{~S}$ \\
\hline \multirow{2}{*}{$\begin{array}{c}\text { Disturbed sleep } \\
\text { BT-DT }\end{array}$} & $\mathrm{A}$ & 17 & 6.000 & 1 & 0.014 & $\mathrm{~S}$ \\
\hline & $\mathrm{B}$ & 20 & 4.000 & 1 & 0.046 & $\mathrm{~S}$ \\
\hline $\begin{array}{c}\text { Carelessness \& forgetfulness } \\
\text { BT-DT }\end{array}$ & $\mathrm{A}$ & 17 & 3.000 & 1 & 0.083 & NS \\
\hline \multirow{2}{*}{$\begin{array}{l}\text { Muscle tension } \\
\text { BT-DT }\end{array}$} & A & 18 & 6.000 & 1 & 0.014 & $\mathrm{~S}$ \\
\hline & $\mathrm{B}$ & 19 & 2.000 & 1 & 0.157 & NS \\
\hline \multirow{2}{*}{$\begin{array}{c}\text { Difficulty in taking decisions } \\
\text { BT-DT }\end{array}$} & A & 18 & 5.000 & 1 & 0.025 & $\mathrm{~S}$ \\
\hline & $\mathrm{B}$ & 19 & 1.000 & 1 & 0.317 & NS \\
\hline \multirow{2}{*}{$\begin{array}{c}\text { Intake of psychoactive substance } \\
\text { BT-DT }\end{array}$} & $\mathrm{A}$ & 3 & 1.000 & 1 & 0.317 & NS \\
\hline & $\mathrm{B}$ & 7 & 1.000 & 1 & 0.317 & NS \\
\hline $\begin{array}{l}\text { Feeling zero at the end of the day } \\
\text { BT-DT }\end{array}$ & $\mathrm{B}$ & 17 & 2.000 & 1 & 0.157 & NS \\
\hline \multirow{2}{*}{$\begin{array}{c}\text { Lack of energy and commitment } \\
\text { BT-DT }\end{array}$} & $\mathrm{A}$ & 18 & 8.000 & 1 & 0.005 & $\mathrm{~S}$ \\
\hline & $\mathrm{B}$ & 19 & 3.000 & 1 & 0.083 & NS \\
\hline
\end{tabular}

Table 2:- Cochran's Test Symptoms Combined effect of Shirolepa and Shiropichu along with concomitant before \& During treatment 


\begin{tabular}{|c|c|c|c|c|c|}
\hline \multicolumn{6}{|c|}{ Chi-Square Tests } \\
\hline Parameters & \multirow{11}{*}{ 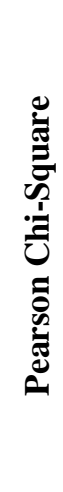 } & Value & Df & Asymp. Sig.(2-sided) & REMARKS \\
\hline Anxiousness & & 8.526 & 1 & 0.004 & $\mathrm{~S}$ \\
\hline Irritability \& Restlessness & & 26.471 & 1 & 0.0001 & $\mathrm{HS}$ \\
\hline Disturbed sleep & & 6.081 & 1 & 0.005 & $\mathrm{~S}$ \\
\hline $\begin{array}{l}\text { Carelessness } \\
\& \text { forgetfulness }\end{array}$ & & 1.778 & 1 & 0.182 & NS \\
\hline Muscle tension & & 9.757 & 1 & 0.002 & $\mathrm{~S}$ \\
\hline Difficulty in taking decisions & & 7.811 & 1 & 0.005 & $\mathrm{~S}$ \\
\hline Intake of psychoactive substance & & 3.600 & 1 & 0.058 & NS \\
\hline Lack of interest in work & & 17.857 & 1 & 0.0001 & HS \\
\hline Feeling zero at the end of the day & & 9.529 & 1 & 0.002 & $\mathrm{~S}$ \\
\hline Lack of energy and commitment & & 4.568 & 1 & 0.033 & $\mathrm{~S}$ \\
\hline
\end{tabular}

Table 3:- Chi-Square Test Symptoms

\begin{tabular}{|c|c|c|c|c|c|c|c|c|c|c|c|c|}
\hline \multicolumn{13}{|c|}{ Wilcoxon Sign Rank Test } \\
\hline \multirow[b]{2}{*}{ 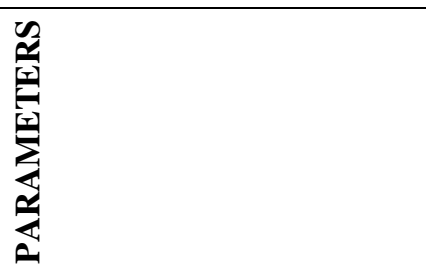 } & \multirow[b]{2}{*}{ 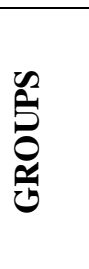 } & \multicolumn{3}{|c|}{ NEGATIVE RANKS } & \multicolumn{3}{|c|}{ POSITIVE RANKS } & \multirow[b]{2}{*}{ 空 } & \multirow[b]{2}{*}{ 岕 } & \multirow[b]{2}{*}{$\begin{array}{c}Z \\
\text { value }\end{array}$} & \multirow[b]{2}{*}{$\begin{array}{c}\mathbf{P} \\
\text { value }\end{array}$} & \multirow[b]{2}{*}{ 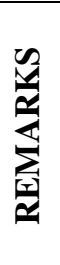 } \\
\hline & & $\mathrm{N}$ & MR & SR & $\mathrm{N}$ & MR & SR & & & & & \\
\hline \multirow{2}{*}{$\begin{array}{c}\text { Stress scale score } \\
\text { DT- AT }\end{array}$} & $\mathrm{A}$ & 18 & 9.50 & 171.00 & 0 & 0.00 & 0.00 & 2 & 20 & -4.066 & 0.0001 & $\mathrm{HS}$ \\
\hline & $\mathrm{B}$ & 20 & 10.50 & 210.00 & 0 & 0.00 & 0.00 & 0 & 20 & -4.072 & 0.0001 & $\mathrm{HS}$ \\
\hline \multirow{2}{*}{$\begin{array}{l}\text { What people think about you } \\
\text { DT- AT }\end{array}$} & $\mathrm{A}$ & 14 & 7.50 & 105.00 & 0 & 0.00 & 0.00 & 6 & 20 & -3.638 & 0.0001 & $\mathrm{HS}$ \\
\hline & B & 17 & 9.00 & 153.00 & 0 & 0.00 & 0.00 & 3 & 20 & -3.879 & 0.0001 & HS \\
\hline \multirow{2}{*}{$\begin{array}{l}\text { Physical symptoms } \\
\text { DT- AT }\end{array}$} & A & 20 & 10.50 & 210.00 & 0 & 0.00 & 0.00 & 0 & 20 & -3.944 & 0.0001 & HS \\
\hline & $\mathrm{B}$ & 20 & 10.50 & 210.00 & 0 & 0.00 & 0.00 & 0 & 20 & -3.985 & 0.0001 & $\mathrm{HS}$ \\
\hline \multirow{2}{*}{$\begin{array}{l}\text { Optimistic } \\
\text { DT- AT }\end{array}$} & $\mathrm{A}$ & 16 & 8.50 & 136.00 & 0 & 0.00 & 0.00 & 4 & 20 & -4.000 & 0.0001 & $\mathrm{HS}$ \\
\hline & B & 16 & 8.50 & 136.00 & 0 & 0.00 & 0.00 & 4 & 20 & -4.000 & 0.0001 & $\mathrm{HS}$ \\
\hline \multirow{2}{*}{$\begin{array}{c}\text { Criticized by superior } \\
\text { DT- AT }\end{array}$} & A & 12 & 6.50 & 78.00 & 0 & 0.00 & 0.00 & 8 & 20 & -3.464 & 0.001 & $\mathrm{~S}$ \\
\hline & B & 16 & 8.50 & 136.00 & 0 & 0.00 & 0.00 & 4 & 20 & -4.000 & 0.0001 & HS \\
\hline \multirow{2}{*}{$\begin{array}{c}\text { Feeling satisfied at the end } \\
\text { of day } \\
\text { DT- AT }\end{array}$} & $\mathrm{A}$ & 9 & 5.00 & 45.00 & 0 & 0.00 & 0.00 & 11 & 20 & -3.000 & 0.003 & $\mathrm{~S}$ \\
\hline & B & 10 & 5.50 & 55.00 & 0 & 0.00 & 0.00 & 10 & 20 & -3.162 & 0.002 & $S$ \\
\hline \multirow{2}{*}{$\begin{array}{c}\text { Amount of work v/s time } \\
\text { DT- AT }\end{array}$} & $\mathrm{A}$ & 13 & 7.00 & 91.00 & 0 & 0.00 & 0.00 & 7 & 20 & -3.606 & 0.0001 & $\mathrm{HS}$ \\
\hline & $\mathrm{B}$ & 13 & 7.00 & 91.00 & 0 & 0.00 & 0.00 & 7 & 20 & -3.606 & 0.0001 & $\mathrm{HS}$ \\
\hline \multirow{2}{*}{$\begin{array}{l}\text { Clear picture of what } \\
\text { expected } \\
\text { DT- AT }\end{array}$} & $\mathrm{A}$ & 16 & 8.50 & 136.00 & 0 & 0.00 & 0.00 & 4 & 20 & -3.900 & 0.0001 & $\mathrm{HS}$ \\
\hline & B & 13 & 7.00 & 91.00 & 0 & 0.00 & 0.00 & 6 & 19 & -3.606 & 0.0001 & HS \\
\hline \multirow{2}{*}{$\begin{array}{l}\text { Bored at work } \\
\text { DT- AT }\end{array}$} & $\mathrm{A}$ & 10 & 5.50 & 55.00 & 0 & 0.00 & 0.00 & 10 & 20 & -3.162 & 0.002 & $\mathrm{~S}$ \\
\hline & $\mathrm{B}$ & 12 & 6.50 & 78.00 & 0 & 0.00 & 0.00 & 8 & 20 & -3.464 & 0.001 & $\mathrm{~S}$ \\
\hline \multirow{2}{*}{$\begin{array}{c}\text { Looking forward in work } \\
\text { DT- AT }\end{array}$} & $\mathrm{A}$ & 7 & 4.00 & 28.00 & 0 & 0.00 & 0.00 & 13 & 20 & -2.646 & 0.008 & $S$ \\
\hline & B & 13 & 7.00 & 91.00 & 0 & 0.00 & 0.00 & 7 & 20 & -3.500 & 0.0001 & HS \\
\hline \multirow{2}{*}{$\begin{array}{c}\text { Expectation before } 10 \text { years } \\
\text { DT- AT }\end{array}$} & A & 13 & 7.00 & 91.00 & 0 & 0.00 & 0.00 & 7 & 20 & -3.606 & 0.0001 & HS \\
\hline & B & 6 & 8.50 & 136.00 & 0 & 0.00 & 0.00 & 4 & 20 & -4.000 & 0.0001 & $\mathrm{HS}$ \\
\hline \multirow{2}{*}{$\begin{array}{l}\text { Like yourself } \\
\text { DT- AT }\end{array}$} & $\mathrm{A}$ & 18 & 9.50 & 171.00 & 0 & 0.00 & 0.00 & 2 & 20 & -4.066 & 0.0001 & HS \\
\hline & B & 18 & 9.50 & 171.00 & 0 & 0.00 & 0.00 & 2 & 20 & -4.146 & 0.0001 & HS \\
\hline
\end{tabular}

Table 4:- Wilcoxon's Test for Symptoms Combined effect of Shirolepa and Shiropichu along with concomitant During treatment and After treatment.

DT- During treatment, AT-After treatment, HS-Highly significant, NS-Non significant, MR-Mean rank, SR-Sum of ranks, Bonferroni correction : $\mathrm{p}<0.016$ 
Mann Whitney U Test

\begin{tabular}{|c|c|c|c|c|c|c|c|c|}
\hline PARAMETERS & 商 & $\mathbf{N}$ & MR & SR & $\begin{array}{c}\text { Mann } \\
\text { Whitney U } \\
\text { value }\end{array}$ & $Z$ value & P value & REMARKS \\
\hline \multirow[t]{2}{*}{ Stress scale score } & A & 19 & 17.05 & 324.00 & \multirow[t]{2}{*}{134.000} & \multirow[t]{2}{*}{-2.080} & \multirow[t]{2}{*}{0.038} & \multirow[t]{2}{*}{ S } \\
\hline & B & 20 & 22.80 & 456.00 & & & & \\
\hline \multirow{2}{*}{$\begin{array}{l}\text { What people } \\
\text { think about you }\end{array}$} & A & 19 & 18.84 & 358.00 & \multirow[t]{2}{*}{168.000} & \multirow[t]{2}{*}{-0.668} & \multirow[t]{2}{*}{0.50} & \multirow[t]{2}{*}{ NS } \\
\hline & B & 20 & 21.10 & 422.00 & & & & \\
\hline \multirow{2}{*}{$\begin{array}{l}\text { Physical } \\
\text { symptoms }\end{array}$} & A & 19 & 14.39 & 273.50 & \multirow[t]{2}{*}{83.500} & \multirow[t]{2}{*}{-3.034} & \multirow[t]{2}{*}{0.002} & \multirow[t]{2}{*}{$\mathrm{S}$} \\
\hline & B & 20 & 25.33 & 506.50 & & & & \\
\hline \multirow[b]{2}{*}{ Optimistic } & $\mathrm{A}$ & 19 & 20.34 & 386.50 & \multirow[t]{2}{*}{183.500} & \multirow[t]{2}{*}{-0.214} & \multirow[t]{2}{*}{0.831} & \multirow[t]{2}{*}{ NS } \\
\hline & B & 20 & 19.68 & 393.50 & & & & \\
\hline \multirow{2}{*}{$\begin{array}{l}\text { Criticized by } \\
\text { superior }\end{array}$} & A & 19 & 21.37 & 406.00 & \multirow[t]{2}{*}{164.000} & \multirow[t]{2}{*}{-0.894} & \multirow[t]{2}{*}{0.371} & \multirow[t]{2}{*}{ NS } \\
\hline & B & 20 & 18.70 & 374.00 & & & & \\
\hline \multirow{2}{*}{$\begin{array}{l}\text { Feeling satisfied } \\
\text { at the end of day }\end{array}$} & $\mathrm{A}$ & 19 & 18.00 & 342.00 & \multirow[t]{2}{*}{152.000} & \multirow[t]{2}{*}{-1.217} & \multirow[t]{2}{*}{0.223} & \multirow[t]{2}{*}{ NS } \\
\hline & $\mathrm{B}$ & 20 & 21.90 & 438.00 & & & & \\
\hline \multirow{2}{*}{$\begin{array}{l}\text { Amount of work } \\
\text { v/s time }\end{array}$} & A & 19 & 21.37 & 406.00 & \multirow[t]{2}{*}{164.000} & -0.894 & 0.371 & NS \\
\hline & B & 20 & 18.70 & 374.00 & & & & \\
\hline Clear picture of & A & 19 & 18.50 & 351.50 & 161.600 & -0.943 & 0.346 & NS \\
\hline & $\mathrm{B}$ & 20 & 21.43 & 428.50 & & & & \\
\hline & $\mathrm{A}$ & 19 & 20.26 & 385.00 & 185.00 & -0.162 & 0.871 & NS \\
\hline Bored at work & $\mathrm{B}$ & 20 & 19.75 & 395.00 & & & & \\
\hline Looking forward & $\mathrm{A}$ & 19 & 19.29 & 366.50 & 176.500 & -0.450 & 0.653 & NS \\
\hline & B & 20 & 20.68 & 413.50 & & & & \\
\hline Expectation & $\mathrm{A}$ & 19 & 17.00 & 323.00 & 133.000 & -1.835 & 0.066 & NS \\
\hline before 10 years & B & 20 & 22.85 & 457.00 & & & & \\
\hline$v_{1}$ & $\bar{A}$ & 19 & 14.42 & 274.00 & 84.000 & -3.413 & 0.001 & $S$ \\
\hline & B & 20 & 25.30 & 506.00 & & & & \\
\hline
\end{tabular}

Table 5:- Comparison On Effect Of Therapy After Treatment 


\begin{tabular}{|c|c|c|c|c|}
\hline $\begin{array}{c}\text { No of } \\
\text { Subjects }\end{array}$ & $\begin{array}{c}\% \\
\text { Improvement in Group-A }\end{array}$ & Remarks & $\begin{array}{c}\% \\
\text { Improvement in Group-B }\end{array}$ & Remarks \\
\hline 1 & $78.72 \%$ & Marked & $78.37 \%$ & Marked \\
\hline 2 & $89.74 \%$ & Marked & $65.45 \%$ & Moderate \\
\hline 3 & $81.39 \%$ & Marked & $63.15 \%$ & Moderate \\
\hline 4 & $62.16 \%$ & Moderate & $58.62 \%$ & Moderate \\
\hline 5 & $83.78 \%$ & Marked & $65.21 \%$ & Moderate \\
\hline 6 & $93.75 \%$ & Marked & $68.96 \%$ & Moderate \\
\hline 7 & $80.00 \%$ & Marked & $55.88 \%$ & Moderate \\
\hline 8 & $82.22 \%$ & Marked & $62.50 \%$ & Moderate \\
\hline 9 & $86.48 \%$ & Marked & $58.33 \%$ & Moderate \\
\hline 10 & $83.72 \%$ & Marked & $45.94 \%$ & Mild \\
\hline 11 & $86.84 \%$ & Marked & $59.45 \%$ & Moderate \\
\hline 12 & $71.42 \%$ & Moderate & $65.21 \%$ & Moderate \\
\hline 13 & $90.47 \%$ & Marked & $86.20 \%$ & Marked \\
\hline 14 & $90.00 \%$ & Marked & $64.28 \%$ & Moderate \\
\hline 15 & $100 \%$ & Marked & $75.67 \%$ & Marked \\
\hline 16 & $78.37 \%$ & Marked & $78.26 \%$ & Marked \\
\hline 17 & $63.63 \%$ & Moderate & $89.74 \%$ & Marked \\
\hline 18 & $61.11 \%$ & Moderate & $83.33 \%$ & Marked \\
\hline 19 & $60.71 \%$ & Moderate & $62.06 \%$ & Moderate \\
\hline 20 & $68.00 \%$ & Moderate & $83.33 \%$ & Marked \\
\hline
\end{tabular}

Table 6 :- Effect of Therapy on Total Score of All the Parameters under Group A and Group B.

The Therapy under Group A provided relief ranging from $60.71 \%$ to $100 \%$, with an average of $79.63 \%$.

The therapy under Group B provided relief ranging from $45.94 \%$ to $89.74 \%$ with an average of $68.50 \%$.

\begin{tabular}{|c|c|c|c|c|}
\hline \multirow{2}{*}{ Response of Therapy } & Group A & \multicolumn{2}{|c|}{ Group B } \\
\cline { 2 - 5 } & No. of Subjects & \% & No. of Subjects & \% \\
\hline Marked Relief & 14 & $\mathbf{7 0 \%}$ & 7 & $\mathbf{6 0 \%}$ \\
\hline Moderate Relief & 6 & $\mathbf{3 0 \%}$ & $\mathbf{1}$ & $\mathbf{5 \%}$ \\
\hline Mild Relief & - & - & - & - \\
\hline No Relief & - & - & & \\
\hline
\end{tabular}

Table 7:- Overall response of therapies in both groups: 


\section{DISCUSSION}

33 the subjects got significant change (with $\mathrm{P}$ value < 0.001 ) in total scale score during treatment and all subjects got significant changes (with $\mathrm{P}$ value 0.0001) after treatment. Antistress, anxiolytic effect and work improvising capacity of drugs used in Shirolepa along with Shankhapushpi ghrita nasya and Tablet might have acted here in multiple aspects of scale. Ashwagandha's withanolides have been researched in a variety of animal studies examining their effect on numerous conditions including immune function and even cancer and is thought to be amphoteric; i.e., it can regulate important physiologic processes86. Satvavajaya chikitsa might have helped especially in pure psychological factors. Satvavajaya chikitsa might have helped in maintaining the positive changes happened. In the symptoms, anxiousness, irritability, disturbed sleep, lack of energy and commitment, stress scale score, physical symptoms, response to criticisms, feeling zero, bowel, what people think about, and optimistic feeling - the study shows significant results after treatment. This may be due to problem solving and relaxing effect of Satvavajaya chikitsa. The combined therapy might have improved the work efficiency and there by reduced the stress. The effect of Satvavajaya, especially response to stressful events and lifestyle modification might have helped in maintaining the combined effect even after stopping the treatment.

\section{CONCLUSION}

Overall effect of therapy showed that, $70 \%$ patient was cured or markedly improved at the end of 60 days of treatment in the Shirolepa group. 30\% patients gained moderate improvement. While in the Shiropichu group 35\% of patients gained marked improvement, 60\% were moderately improved while $5 \%$ were having mild improvement.

Hence, it can be concluded that, improvement in the Shirolepa group was more significant and consistent as compared to Shiropichu group.

By seeing the results it's evident that no patient had complete remission after 7 days of Shirolepa/Shiropichu. This implies that only Shirolepa or Shiropichu is insufficient for the management of Chittodwega (OS). After completion of the treatment (60days) Subjects got marked relief in the symptoms.

\section{REFERENCES}

[1]. Lovallo WR.US. Stress and health biological and psychological interactions. Ed.2. California; Sage publications.1997;p.124

[2]. Paradakara HSS, Ashtanga Hridaya with Sarvanga Sundari Commentry by Arunadatta and Ayurveda Rasayana of Hemadri. 9th ed. Varanasi: Krishnadas Academy; 1995; P.792

[3]. Charaka, Dridhabala. In. Acharya JT, The Charaka samhita of Agnivesa with the Ayurveda dipika commentary by Chakrapani data. 5th ed. Varanasi; Chaukhambha Orientalia. 1995; P.113

[4]. Jyotir mitra. Ashtanga Samgraha with Sasilekha Sanskrit Commentry by Indu.3rd ed.Varanasi: Chowkhamba Sanskrit series office.2000;p.376

[5]. Acharya JT. Susrutasamhita of Susruta with Nibandhasangraha Commentary of Dalhanacharya. Varanasi: Choukambha Sanskrit samsthan. 2013;p.157

[6]. Charaka, Dridhabala. In. Acharya JT, The Charaka samhita of Agnivesa with the Ayurveda dipika commentary by Chakrapani data. 5th ed. Varanasi; Chaukhambha Orientalia. 1995; P.299

[7]. Rajanighantu-Tripathi Indradev, Editor, Raja Nighantu of Pandit Narahari, Fourth edition, Ch 6. Ver 82, Varanasi, Choukhambha Krishnadas Academy, 2006; P.83

[8]. Bhavaprakasa nighantu- G.S Pandey, Editor, Bhavaprakasa nighantu of Bhavamisra with commentary by Chunekar, Reprint edition, Ch 1, Ver 162-164, Choukhambha Bharathi Academi, P.393

[9]. Kaiyadeva nighantu- Sharma PV and Sharma Guru Prasad, Kaiyadeva Nighantu, Reprint edition, Ch. 1,Ver:1041-1043 Varanasi, Choukhambha orientalia, 2009; p.193

[10]. Rastogi RP, Mehrotra BN, Compendium of Indian Medicinal Plants, Vol. 6. Central Drug Research Institute, New Delhi, 1998

[11]. Grandhi, A. Journal of Ethnopharmacology (Ireland), vol. 3.1994; 131-135

[12]. Ajay Padmawar; Withania somnifera. Monograph for Anruta Herbals, LTD.

[13]. Bone K; Clinical Applications of Ayurvedic and Chinese Herbs. Queensland, Australia:Phytotherapy Press, 1996, p.137-41.

[14]. Bhattacharya A, Ghosal S, Bhattacharya SK. Antioxidant effect mice. J Pharm Pharmacol 1998;50:1065-1068 